East European Journal of Physics

East Eur. J. Phys. 1. 99-103(2021)

DOI: $10.26565 / 2312-4334-2021-1-13$

PACS: 52.75.-d,52.77.-j,52.80.Hc,52.90.+z,82.33.Xj

\title{
PLASMA CHEMICAL METHOD OF DECREASING THE ETHYLENE IMPURITIES IN THE AIR
}

\author{
Leonid M. Zavada ${ }^{\dagger}$, Dmytro V. Kudin* \\ Institute of Plasma Electronics and New Acceleration Methods \\ National Scientific Center "Kharkiv Institute of Physics and Technology" NASU \\ Kharkiv, 61108, st. Akademicheskaya 1, Ukraine \\ *Corresponding Author: kudin@kipt.kharkov.ua \\ †E-mail:zavadal@kipt.kharkov.ua \\ tel./fax +38(057)335-61-87 \\ Received December 21, 2020; revised January 18, 2021; accepted February 19, 2021
}

\begin{abstract}
The efficiency of ethylene impurities decomposition in barrierless plasma-chemical system during artificial injection into the air of a sea container has been studied. The experimental study was performed at the air temperature $5^{\circ} \mathrm{C}$ in container volume $65 \mathrm{~m}^{3}$. The initial level of ozone in the air was $100 \mathrm{ppb}$. This concentration is below concentration which audible to humans. It has been established that the use of a carbon filter after a plasma chemical system allows to maintain the ozone content in the air at an acceptable level (in terms of human health and food storage). During 24 hours the ethylene concentration increases until an equilibrium concentration is reached. After the plasma chemical rector was switched on, the ethylene concentration in the container began to decrease due to decomposition in the low-temperature plasma and interaction with ozone until new equilibrium concentration was reached. The ozone concentration after plasma chemical reactor was switched to begin increased. After 1 hour, the new minimum equilibrium ethylene and ozone concentration was established. The decrease in concentration occurred exponentially and reached a new equilibrium concentration above zero, which is consistent with the theory. The increase in ozone concentration occurs by about $20-25 \%$. It has been shown that using plasma chemical system based on barrierless plasma chemical reactors can reduce the ethylene concentration by up to 10 times, even for low concentrations of ethylene in the air.
\end{abstract}

KEYWORDS: ethylene, plasma chemistry barrierless reactor.

During storage and transportation of many types of fruits and vegetables there is an increase in the concentration of ethylene due to biochemical reactions [1]. The concentration of ethylene that can be generated in this way during storage of vegetables and fruits varies in a wide range from 1.3-1.5 ppm for tomatoes [2] to 30-40 ppm for eggplants [3] or plums [4]. Increasing the ethylene concentration in the air significantly accelerates the processes of maturation and spoilage [5]. And the task of controlling the level of ethylene is difficult due to low concentrations (1-40 ppm) and large volumes of air to be treated [6]. As shown in [7], low-temperature plasma of barrierless gas discharge can be used to control the content of ethylene in the air of a sea container used for the transportation of fruits and vegetables. In gas discharge atmospheric pressure in air is also generated ozone. For effective use of this method in transportation and storage of vegetables and fruits requires a more detailed study of the efficiency and stability of oxidation of ultra-low concentrations of ethylene by plasma chemical reactors and ozone influence. It should be noted that a significant number of fruits are sensitive to ozone and it can have both positive (mold suppression [8,9]) and negative (spoilage of products and loss of attractive appearance) effect. The air can be purified from ozone with a filter based on carbon or oxide catalysts. However, reducing the filter load and the cost-effectiveness of using a plasma chemical system to oxidize ethylene impurities in air to levels below harmful levels requires a study of the effect of concomitant low ozone concentrations on the efficiency of ethylene oxidation.

\section{EXPERIMENTAL SETUP AND METHODS}

The experimental study was performed in a 40-foot sea container with a volume of $65 \mathrm{~m}^{3}$, which was cooled to $5{ }^{\circ} \mathrm{C}$. Figure 1 shows a diagrammatic representation of a container with a plasma chemical system.

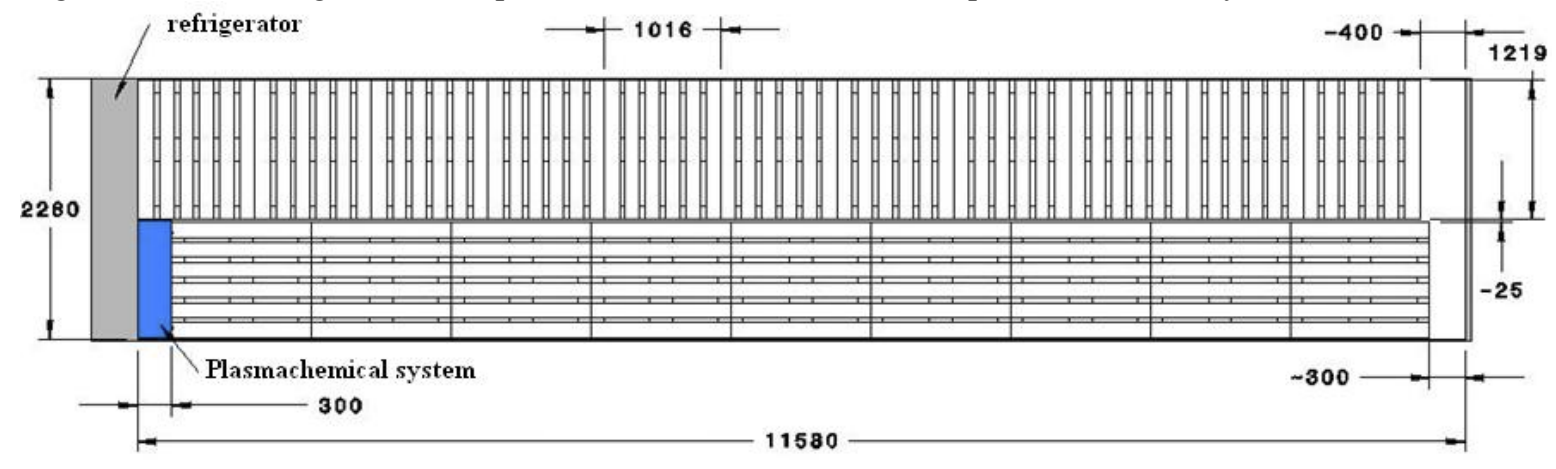

Figure 1. The diagrammatic representation of a container with a plasma chemical system. 
The plasma chemical system consisted of two units, each of which included 12 plasma chemical reactors (PCRs) with 10 star-shaped [9] electrodes and a high-voltage power supply unit with a capacity of $285 \mathrm{~W}$ each.

The photo (Fig. 2) shows a general view of the plasma chemical system.
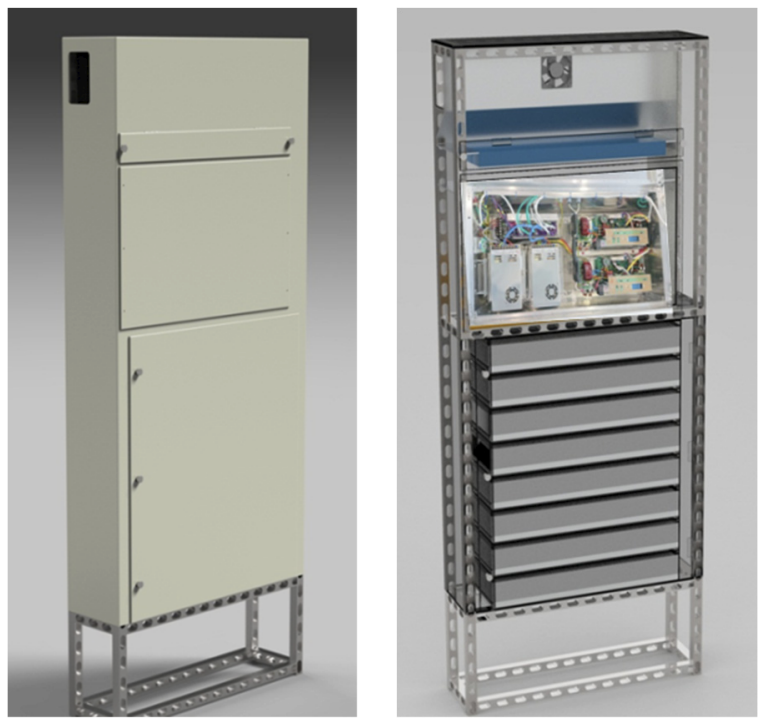

Figure 2. The photos of plasma chemical system with closed and open outer cover.

The plasma chemical oxidation system of ethylene operated in three modes: standby mode (plasma chemical system off, fans off), ventilation mode (3 fans on), operating mode (plasma chemical system on, 1 or 3 fans on depending on the ozone system setting). The carbon filter consisted of 8 containers. The total weight of activated carbon was $70 \mathrm{~kg}$.

Figure 3 shows the photo of the container with the distribution of sensors for measuring the concentration of ozone and ethylene to determine the uniformity of air treatment in the middle and a photo of the location of the plasma chemical system in the container.

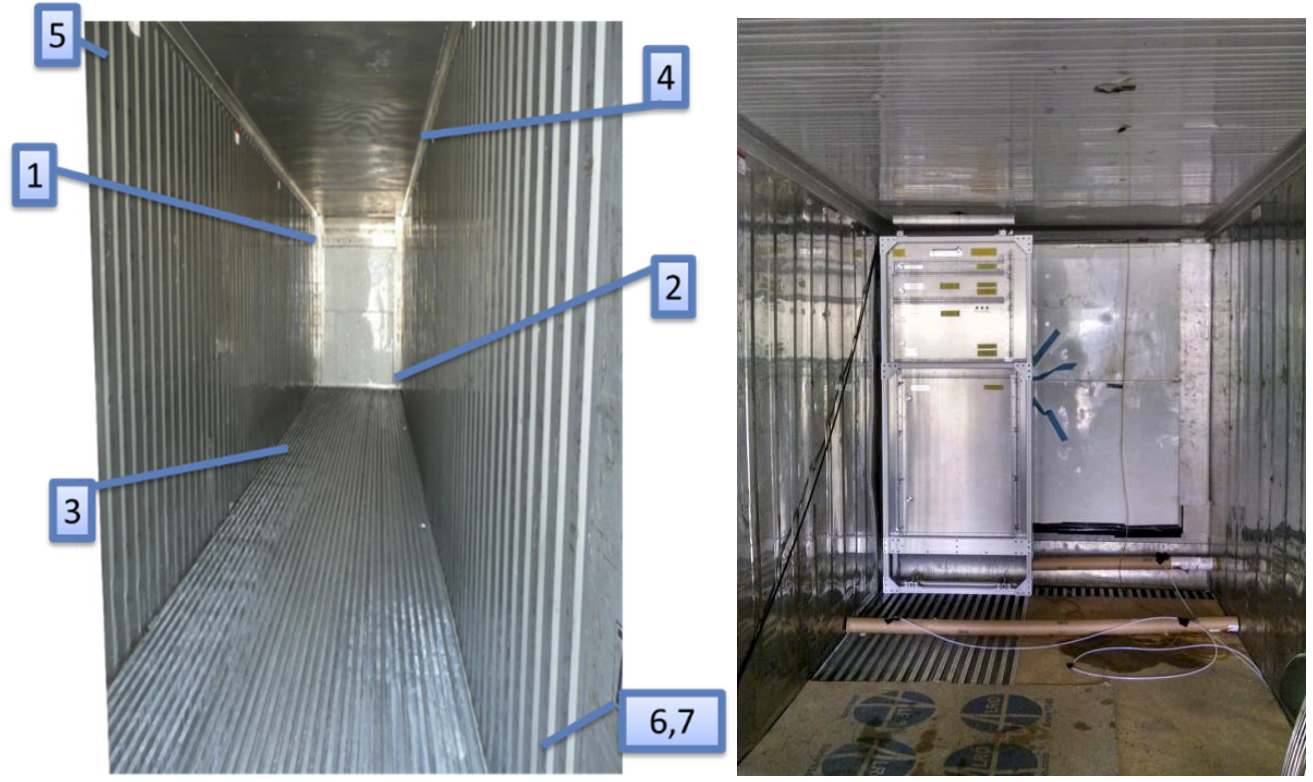

Figure 3. Distribution of sensors inside the container and location of the plasma chemical system.

The ethylene concentration values were averaged for all sensors located in the container. The ethylene was fed into the container from a 40-liter cylinder through a reducer and a control flow meter "Alicat scientific". The air in the container was forcibly circulated by an external air pump at a rate of $1 \mathrm{l} / \mathrm{min}$. The ethylene and ozone concentrations, as well as air temperature and moisture content were measured by sensors located in the container. The ethylene concentration was measured with an ICA56 meter and monitored by sampling from a circulating line, which was analyzed by a Thermo Scientific "Trace 1310" gas chromatograph with a flame ionization detector. Samples were taken in different control points of the circulation line (in the middle of the container, near the door and at the end, at different heights) with a $1 \mathrm{ml}$ syringe. The chromatograph was pre-calibrated with calibration gas mixtures with ethylene content of 10 and $100 \mathrm{ppm}$. 


\section{RESULTS AND DISCUSSIONS}

At the first stage of research the change of ozone concentration in the container depending on time at the maximum power which applied to plasma chemical reactor with system of recirculation of air through the carbon filter is measured (Fig. 4).

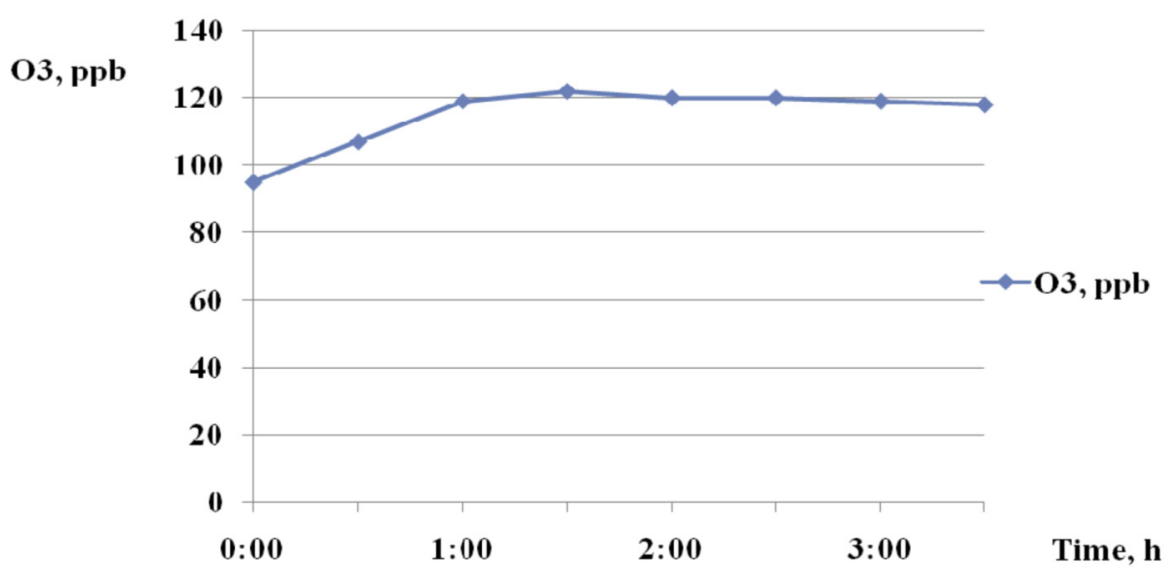

Figure 4. Dependences of ozone concentration inside the container on time. Power $820 \mathrm{~W}$.

The initial level of ozone in the air was higher than 0 , but below the concentrations audible to humans. Reaching the maximum value of ozone concentration occurs within 1 hour. The ozone concentration level after switch on plasma chemical reactor increase in occurs by about $20-25 \%$. It is seen that the carbon filter is quite effective in reducing the concentration of ozone, keeping it at a low level.

The concentration of ozone and ethylene in an empty container by artificially filling ethylene at a flow rate of 1 and $4 \mathrm{~cm}^{3} / \mathrm{min}$ was measured. On Fig. 5 is shown graphs of the dependence of the concentration of ozone and ethylene on time at different flows of $\mathrm{C}_{2} \mathrm{H}_{4}$ and at the applied power to the plasma chemical reactor $820 \mathrm{~W}$.

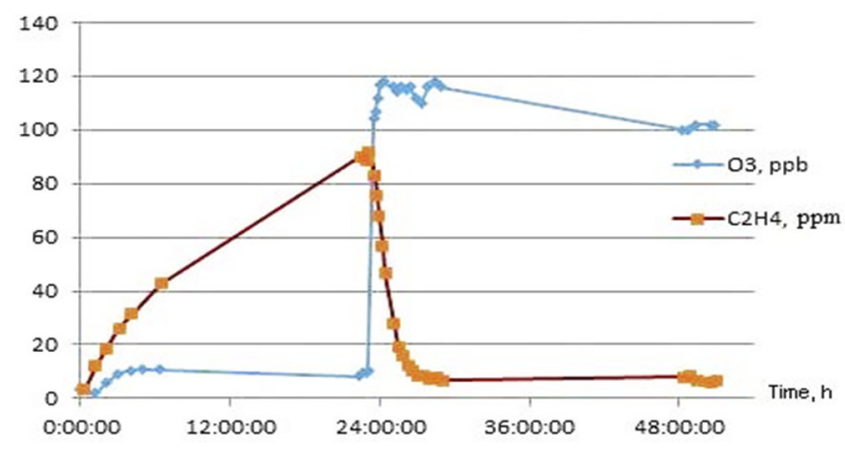

a

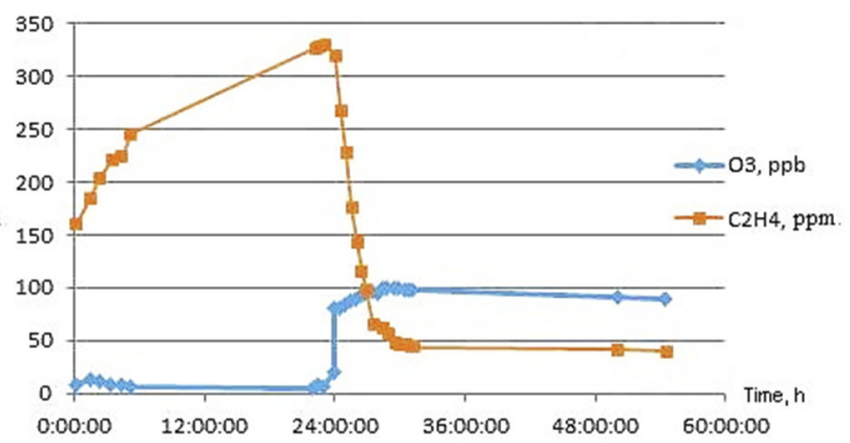

$\mathrm{b}$

Figure 5. The dependence of ozone and ethylene concentration on the time (a - ethylene flow rate $1 \mathrm{sccm}, \mathrm{b}-4 \mathrm{sccm}$ ).

The graphs show that the concentration of ethylene initially increases, until an equilibrium concentration is reached in the container (approximately 24 hours). After reaching the equilibrium concentration of ethylene, the plasma chemical rector was switched on, the ozone concentration in the container began to increase until equilibrium was reached, and the ethylene concentration decreased due to decomposition in the plasma chemical reactor and interaction with ozone. After approximately 1 hour, the minimum equilibrium concentration of ethylene was established, which was determined by the rate of ethylene supply to the container.

To determine the law of decreasing ethylene concentration, the part of the dependence where the significant decrease occurs was considered. The graph (Fig. 6) shows the dependence of the rate of decrease of the reduced concentration of ethylene $\left(\left[\mathrm{C}_{2} \mathrm{H}_{4}\right] /\left[\mathrm{C}_{2} \mathrm{H}_{4}\right]_{0}\right)$ on time at different consumption of ethylene.

It can be seen that the graphs of decline are exponential in nature and agree well with the theoretical calculation.

The dependence of the decrease in the reduced concentration of ethylene on time is analyzed.

$$
\left[\mathrm{C}_{2} \mathrm{H}_{4}\right] /\left[\mathrm{C}_{2} \mathrm{H}_{4}\right]_{0}=\exp \left\{-\mathrm{t} / \mathrm{t}_{\mathrm{o}}\right\}
$$

where $\left[\mathrm{C}_{2} \mathrm{H}_{4}\right]_{0}$ - equilibrium concentration $\mathrm{C}_{2} \mathrm{H}_{4}$ without plasma reactors, $\mathrm{t}_{0}$ - half-life $\mathrm{C}_{2} \mathrm{H}_{4}$. 


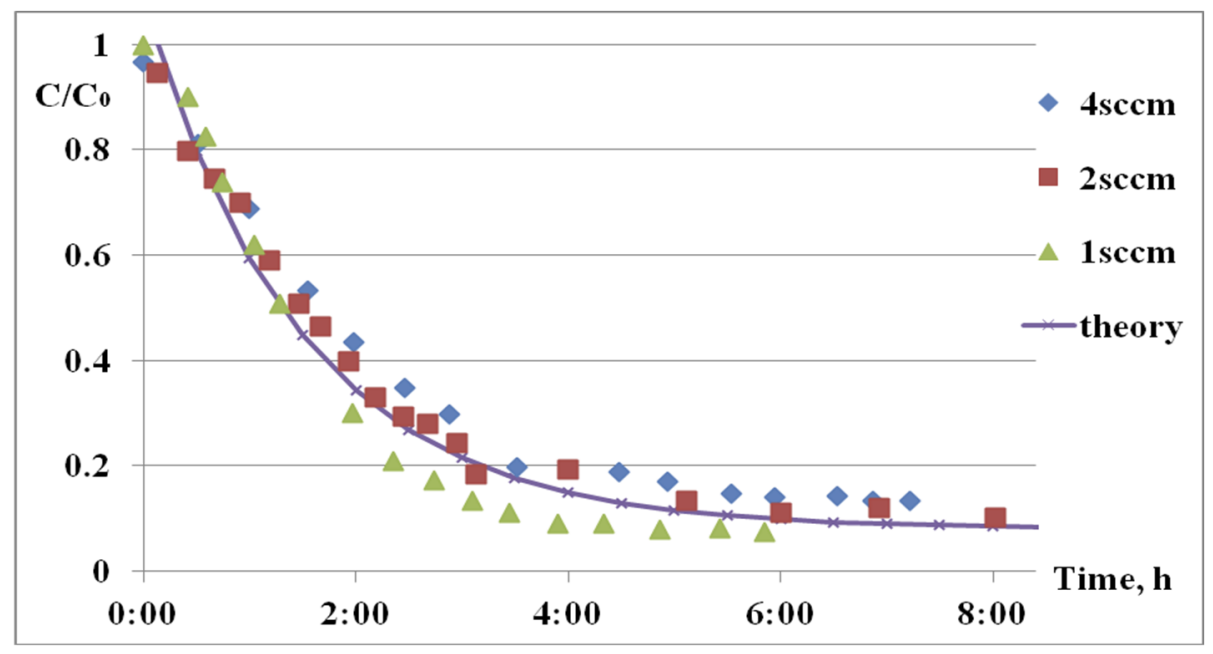

Figure 6. The rate of decrease of ethylene concentration at different injection rates (1-4 sccm).

In Table 2 is shown the data on the maximum (excluding the plasma chemical system) and minimum ethylene content in the sea container at different injection of ethylene.

Table 2. The degree of decomposition of ethylene in the plasma chemical system.

\begin{tabular}{|l|c|c|c|}
\hline & $\mathbf{1} \mathbf{~ s c c m ~} \mathbf{C}_{2} \mathbf{H}_{\mathbf{4}}$ & $\mathbf{2} \mathbf{s c c m} \mathbf{C}_{\mathbf{2}} \mathbf{H}_{\mathbf{4}}$ & $\mathbf{4} \mathbf{s c c m} \mathbf{C}_{\mathbf{2}} \mathbf{H}_{\mathbf{4}}$ \\
\hline Applied power, W & 800 & 820 & 820 \\
\hline $\mathrm{O}_{3}, \mathrm{ppb}$ & 105 & 115 & 140 \\
\hline Max $\mathrm{C}_{2} \mathrm{H}_{4}, \mathrm{ppm}$ & 7,2 & 11,2 & 31,1 \\
\hline Min $\mathrm{C}_{2} \mathrm{H}_{4}, \mathrm{ppm}$ & 0.5 & 1,1 & 3,8 \\
\hline
\end{tabular}

The table shows that the presence of a plasma chemical system reduces the ethylene content in the container by about 10 times at different injection of ethylene.

The graph (Fig. 7) shows the dependence of the ethylene concentration decrease rate in the container on time at different concentrations of residual ozone $(5,1$ and $0 \mathrm{ppm})$.

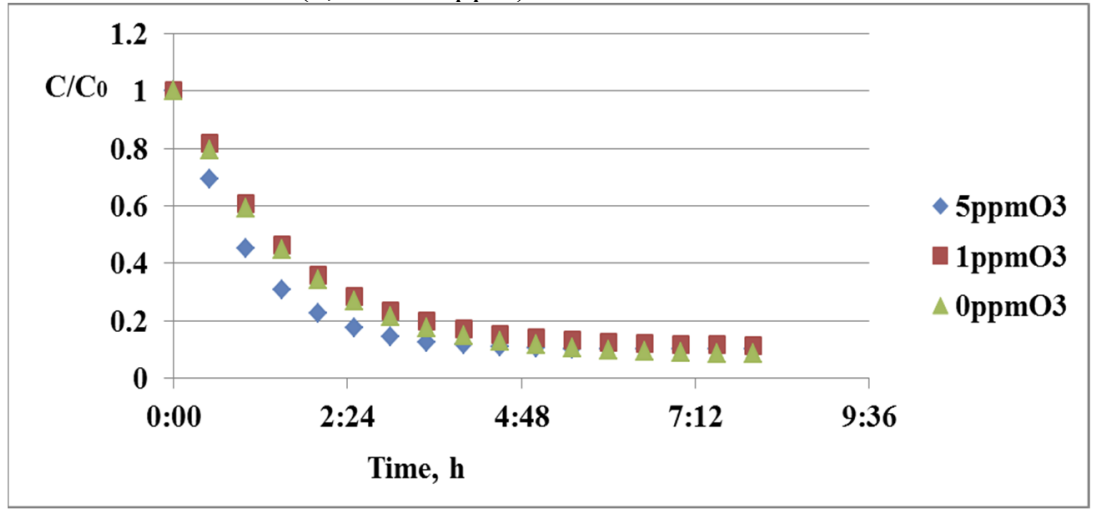

Figure 7. The rate of ethylene concentration decrease after the inclusion of the plasma chemical system at different concentrations of residual ozone.

From the above graphs it is seen that with increasing residual ozone concentration, the rate of decline of ethylene concentration increases, but over time it reaches the same stationary concentration, according to the theory [11].

Table 3 shows the half-life of ethylene at different concentrations of residual ozone.

Table3. The half-life of ethylene in the container.

\begin{tabular}{|c|c|c|c|}
\hline $\mathbf{O}_{\mathbf{3}}$ & $\mathbf{0} \mathbf{p p m}$ & $\mathbf{1} \mathbf{p p m}$ & $\mathbf{5 p p m}$ \\
\hline $\mathrm{t}_{0}, \mathrm{~min}$ & 91 & 86 & 57 \\
\hline
\end{tabular}

The table shows that the presence of residual ozone in the container reduces the half-life of ethylene by $40 \%$. Thus, the presence of a small concentration of residual ozone can accelerate the process ethylene impurities 
decomposition with the inclusion of the plasma chemical system. For some vegetables and fruits, the harmful effects of ethylene become noticeable from concentrations much higher than those that can be obtained using the plasma chemical method of ethylene decomposition, so they may have more energy-efficient regimes that reduce either the power applied in the discharge or the plasma chemical system is switched on with some periodicity, which requires additional methodological instructions for the use of the described method in the storage of a specific type of fruit and vegetable products.

\section{CONCLUSIONS}

It has been shown that using a plasma chemical system based on barrierless plasma chemical reactors can reduce the ethylene concentration by 10 times or more, even for low concentrations of ethylene in the air. It has been established that the use of a carbon filter after a plasma chemical system allows to maintain the ozone content in the air at an acceptable level (in terms of human health and food storage).

For each type of fruit and vegetable products it is necessary to form methodological guidelines for the use of plasma-chemical method of ethylene oxidation to increase its energy efficiency and economic feasibility.

\section{ORCID IDs}

○Leonid M. Zavada, https://orcid.org/0000-0002-7248-1400; @Dmytro V. Kudin, https://orcid.org/0000-0002-6704-1582

\section{REFERENCES}

[1] A.A. Kolesnik Factors of long-term storage of fruits and vegetables, (Gostorgizdat, Moscow, 1959), pp. 356. [in Russian]

[2] A. Nakatsuka, S. Murachi, H. Okunishi, S. Shiomi, R. Nakano, Y. Kubo, and A. Inaba, Plant Physiol, 118, 1295-1305 (1998), https://doi.org/10.1104/pp.118.4.1295.

[3] A. Concellón, María C. Añón, and A.R. Chaves, Food Chemistry, 92, 63-69 (2005), https://doi.org/10.1016/j.foodchem.2004.04.048.

[4] Li Dong, Susan Lurie, Hong-Wei Zhou, Postharvest Biology and Technology, 24, 135-145 (2002), https://doi.org/10.1016/S0925-5214(01)00130-2.

[5] W. Crocker, A.E. Hitchcock, and P.W. Zimmerman, Similarities in the effects of ethylene and the plant auxins, in: Contrib. Boyce Thompson Inst. 7(3), 1935, pp. 231-248.

[6] K. Golden, Asian Journal of Biological Sciences, 7(4), 135-143 (2014), https://doi.org/10.3923/ajbs.2014.135.143.

[7] V.I. Golota, D.V. Kudin, O.V. Manuilenko, G.V. Taran, L.M. Zavada, M.O. Yegorov, and V.F. Khmelevskaya, Problems of Atomic Sci. and Technol. Ser. Plasma Electronics and New Methods of Acceleration, 4(116), 160-163 (2018), https://vant.kipt.kharkov.ua/ARTICLE/VANT_2018_4/article_2018_4_160.pdf.

[8] G.V. Taran, V.A. Breslavets, A.A. Zamuriev, M.O. Yaroshenko, P.O. Opalev, and O.V. Maiboroda, PAST, 4(122), 198-202 (2019), https://vant.kipt.kharkov.ua/ARTICLE/VANT_2019_4/article_2019_4_198.pdf.

[9] V.I. Golota, G.V. Taran, A.A. Zamuriev, P.O. Opalev, S.G. Pugach, S.N. Mankovskyi, V.P. Petrenkova, and I.N. Nyska, PAST, 116(4), 185-188 (2018), https://vant.kipt.kharkov.ua/ARTICLE/VANT_2018_4/article_2018_4_185.pdf

[10] V. Golota, O. Yegorov, V. Mykhaylov, V. Mukhin, G. Taran, and S. Shilo, US Patent No. 6, $\overline{5} 4 \overline{4}, 486$ B2 (18 April, 2003$).$

[11] O.V. Manuilenko, D.V. Kudin, A.Y. Dulphan, V.I. Golota, PAST, 116(4), 139-143 (2018), https://vant.kipt.kharkov.ua/ARTICLE/VANT_2018_4/article_2018_4_139.pdf

\section{ПЛАЗМОХІМІЧНИЙ МЕТОД ЗМЕНШЕННЯ ДОМІШКИ ЕТИЛЕНУ У ПОВІТРІ}

Завада Л.М., Кудін Д.В

Інститут плазмової електроніки та нових методів прискорення

Наиіональний Науковий Центр "Харківський Фізико-Технічний Інститут», Харків, Україна

Досліджено ефективність окиснення домішки етилену безбар'єрною плазмохімічною системою при штучному інжектуванні у повітря морського контейнеру. Експериментальне дослідження проводилось при температурі повітря $5{ }^{\circ} \mathrm{C}$ в об’ємі 65 м ${ }^{3}$. Початковий рівень озону в повітрі становив $100 \mathrm{ppb}$. Ця концентрація нижча за концентрацію, яка чутна для людей. Таким чином встановлено, що використання вугільного фільтру після плазмохімічної системи дозволяє підтримувати вміст озону у повітрі на припустимому (з точки зору здоров'я людей та зберігання продуктів) рівні. Протягом 24 годин концентрація етилену зростає до досягнення рівноважної концентрації. Після включення плазмохімічного ректора концентрація етилену в контейнері почала зменшуватися через розкладання в низькотемпературній плазмі та взаємодію 3 озоном до досягнення нової рівноважної концентрації. Концентрація озону після включення плазмохімічного реактора почала зростати. Через 1 годину було встановлено нову мінімальну рівноважну концентрацію етилену та озону. Спадання концентрації відбувалося за експоненціальним законом та досягало нової рівноважної концентрації вище нуля, що відповідає теорії. Збільшення концентрації озону відбувається приблизно на 20-25\%. Продемонстровано, що при використанні плазмохімічної системи на базі безбар'єрних плазмохімічних реакторів можливо зниження концентрації етилену до 10 разів навіть для низьких концентрацій етилену у повітрі.

КЛЮЧОВІ СЛОВА: етилен, плазмохімічний безбар'єрний реактор 